\title{
INTERNATIONAL BUSINESS BOOKS/PUBLICATIONS RECEIVED BETWEEN JANUARY 1, 2002 AND MARCH 31, 2002
}

Banking, Capital Markets and Corporate Governance, Hiroshi Osano and Toshiaki Tachibanaki (editors), Global Publishing and St.Martin's Press, New York, NY (2002) $\$ 72.00$ US.

The Changing Economic Environment in Asia: Firms' strategies in the Region, Bernadette Andreosso-O'Callaghan, Jean-Pascal Bassino and Jacques Jaussaud (editors), Palgrave, New York, NY (2002) \$70.00 US.

China and the Global Business Revolution, Peter Nolan, Palgrave, New York, NY (2001) $\$ 100.00$ US.

Creative Management $2^{\text {nd }}$ Edition, Jane Henry (editor), Sage Publications, Thousand Oaks, CA (2001).

Designing Organizations: An Executive Guide to Strategy, Structure and Process, Jay R. Galbraith, Jossey-Bass, San Francisco, CA (2002) \$35.00 US.

Doing Action Research in Your Own Organization, David Coghlan and Teresa Brannick, Sage Publications, Thousand Oaks, CA (2001).

Entrepreneurship and Small Business, Paul Burns, Palgrave, New York, NY (2002) $\$ 79.95$ US.

From Local Champions to Global Masters: A Strategic Perspective on Managing Internationalization, Paul Verdin and Nick Van Heck, Palgrave, New York, NY (2001) \$39.95 US.

Globalizing Europe: Deepening Integration, Alliance Capitalism and Structural Statecraft, Thomas L. Brewer, Paul A. Brenton and Gavin Boyd, Edward Elgar, Northampton, MA (2002).

Grounded Theory in Management Research, Karen Locke, Sage Publications, Thousand Oaks, CA (2001).

The Human Value of the Enterprise: Valuing People as Assets-Monitoring, Measuring, Managing, Andrew Mayo, Nicholas Brealey Publishing, London, UK (2001) \$29.95 US.

Inside Japanese Business: A Narrative History, 1960-2000, Makoto Ohtsu and Tomio Imanari, M.E. Sharpe, Armonk, NY (2002) \$29.95 US.

Managing Industrial Knowledge: Creation, Transfer and Utilization, Ikujiro Nonaka and David Teece (editors), Sage Publications, Thousand Oaks, CA (2001).

Multinationals in a New Era: International Strategy and Management, James $\mathrm{H}$. Taggart, Maureen Berry and Michael McDermott (editors), Palgrave, New York, NY (2002) $\$ 65.00$ US.

Organizational Behaviour Reassessed: The Impact of Gender, Elisabeth Wilson (editor), Sage Publications, Thousand Oaks, CA (2001).

The Psychology of Management in African Organizations, Denis Chima E. Ugwuegbu, Quorum Books, Westport, CT (2001).

Researching the Small Enterprise, James Curran and Robert A. Blackburn, Sage Publications, Thousand Oaks, CA (2001)

Work, Postmodernism and Organization: A Critical Introduction, Philip Hancock and Melissa Tyler, Sage Publications, Thousand Oaks, CA (2001). 